\title{
A REVIEW OF THE INCLUSION PROCESS OF SYRIAN REFUGEE STUDENTS IN THE FORMAL EDUCATION SYSTEM OF TURKEY
}

\author{
Melike Özyurt ${ }^{1}$ \\ Gaziantep University, Turkey \\ Bilge Kuşdemir Kayıran \\ Gaziantep University. Turkey
}

Şükran Tüfekçi Küçükoğlu

Ministry of National Education, Turkey

\begin{abstract}
The purpose of this study is to examine the opinions of classroom teachers, administrators, students, and parents regarding the inclusion of refugee students in Turkey's formal education system. The research is a qualitative study with a case study model. The study was performed with 24 classroom teachers, 8 administrators, 12 Turkish and 12 refugee students and the parents of 8 Turkish and 8 refugee students from 3 primary schools. Semi-structured interview forms were used as data collection tools in the study. As a result of the study, all the stakeholders uttered that the process regarding the inclusion of refugee students in formal education enabled cooperation, socialization and to be familiar with a different culture, and it also supported the orientation process though some language/communication problems occurred. The process was characterized to be unfruitful due to the reasons such as adaptation problems, the disruption of education, the emergence of behavioural problems and the deterioration of classroom arrangement. While Turkish students mostly indicated that they were not satisfied with the implementation, refugee students pointed out that they were happy to go to school. In addition to the inclass and school-wide efforts such as getting assistance from the guidance service and promoting learning Turkish and adapting to school during the process. It was observed that there was no unity in practice among schools and some of them were realized through the individual initiatives of teachers. It was established that the most frequent suggestions for increasing the efficiency of the process were to ensure refugee students and their families to learn Turkish, and to include the students in formal education after the orientation process.
\end{abstract}

Keywords: Refugee, refugee students, primary education, inclusion process, social inclusion

${ }^{1}$ Correspondence: Email for each author, respectively, is: melike.ozyurt@yahoo.com; kbilgeo1@gmail.com; skrntfkc@gmail.com 


\section{Introduction}

Recent events in the Middle East brought the concept of immigration close to the top of the agenda of the entire world. In fact, immigration is not an unknown concept for humanity. Throughout history, people have immigrated for various reasons such as natural disasters, wars, famine, and poverty (Koç, Görücü \& Akbiyık, 2015). The concept of immigration can also be explained as the settling of people in a different region to live for a certain period, or for the rest of their lives (Tunç, 2015). On the other hand, forced migration, which might be due to natural disasters, wars, violence, etc. (Özkarsl1, 2014), is displacement of many people in a country through forced methods (Pala, 2013).

The social movement known as the "Arab Spring" which started in Tunisia in 2010 and influenced Syria in 2011, caused a wave of migration on the borders of Turkey which highly affected Europe as well. Due to the conflicts and violence in the country, of Syria's population of 23 million, more than 7 million people were forced to be asylum-seeker in neighbouring countries, mainly in Turkey, and about 7 million displaced within the country (Connor, 2018). Turkey has been the mostly affected country by this situation (Banks, 2017, Bogotch \& Kervin, 2019). Accepting the Geneva Convention of 1951 on the condition of geographical limitation, Turkey granted "temporary protection" status to Syrian refugees, as the country could not take Syrian refugees in the scope of asylum seekers, and opened the borders to refugees following an "open door" policy (Oytun \& Gündoğar, 2015). Temporary protection is an urgent and temporary protection measure enabled by the decision of the Council of Ministers in Turkey when the personal international protection application mechanism of mass migration movement cannot be implemented effectively (Directorate General of Migration Management, 2016). Syrian refugees who are granted temporary protection status are entitled to stay in Turkey as long as they want (Oytun \& Gündoğar, 2015).

Although the rights of Syrians, who took refuge and were born in Turkey, such as education, nutrition, health, security and access to information are guaranteed by the "Law on Foreigners and International Protection" (Bulut, 2015), it can be said that one of the issues that influence refugee children the most is education. Because, as of 2011, education was interrupted in many schools in Syria due to the civil war (Akpinar, 2017; SCPR, 2015; UNICEF Connect, 2015), and refugee children who were living outside the camps could not reach educational opportunities for a long period after taking refuge in Turkey (Yavuz \& Mizrak, 2016). Therefore, around 400,000 refugee children have remained outside the school system since 2011 (Akpinar, 2017).

In this period, serious efforts have been undertaken to ensure the educational rights of refugee children in Turkey. In this context, temporary education centres (TEC) were firstly established in the camps where the Syrians resided, and textbooks were provided free of charge to the students (Özcan, 2018) similar to those in other refugee-accepting countries (Bogotch \& Kervin, 2019; Charles \& Denman, 2013). Together with the settlement of Syrians residing in camps into the cities, double shift schooling was started in schools in those city centres. Like the practice carried out in Lebanon (Khattab, 2017), Syrian students were educated in these schools by making use of all their technical and physical equipment in the afternoons following Turkish students in the mornings. In addition to giving education to refugees in their own language, Turkish education was essential at these centres (Taştan \& Çelik, 2017). It was ensured that the education program at the TECs is prepared under the control of the Ministry of National Education and that Turkish class and vocational training classes are opened for Syrians who do not speak but want to learn Turkish. Thus, it was aimed to offer a qualified education to Syrian children, 
who had to discontinue their education, so that they would not miss a year (Ministry of National Education, 2013).

In addition to the efforts at the TECs, various other efforts have been made to educate Syrian children living in cities. At the special education centres supported by international organizations and non-governmental organizations, Syrian students were provided with an education program largely consistent with the education program which applied in Syria (Seydi, 2014). However, after the idea that Syrian people would stay in Turkey for the long term became established, the path to follow for including Syrian refugee students within the Turkish education system was identified with a circular titled "Educational Services for Foreign Nationals" published on 23 September 2014 which ensured a systematic and organized education, and provincial commissions of the Directorate of National Education were assigned with carrying out the equivalence, transfer and placement procedures of Syrian students (Ministry of National Education, 2014).

Moreover, as part of the 2015-2019 Strategical Plan of the Ministry of National Education, targets were identified to create equivalence programs for Syrians to be more functional, and the "Educational Department for Migration and Emergency Situation" was established within the Ministry of National Education to develop long-term and comprehensive policies for access to qualified education by not only the children under temporary protection status, but also every child within Turkey's borders, and adaptation processes were accelerated accordingly. Starting from the 2016-2017 academic year, efforts to include these students in formal education in Turkey were performed. Within this scope, Syrian students in the first grades of primary schools and secondary schools were enrolled at Turkish schools with foreigner identification certificates without the condition of a residence permit (Özcan, 2018).

Another application supporting the educational process of refugee students is the Provincial Directorates of National Education recognition of diploma equivalency of students who completed their primary and secondary education in Syria and applied for equivalency. This way, students who passed the Turkish language exam were given the chance to receive higher education at Turkish universities (Sandal, Hançerkıran \& Tiraş, 2016). In addition to these efforts, Turkish language classes were opened at Public Education Centres and the Turkish language proficiency of Syrian refugees was improved to facilitate their adaptation to society. As a result of all these regulations, an increase was observed in school attendance of Syrian children (Saklan, 2018), and this was resulted in the conduct of educational activities in multicultural classroom settings.

Priorities and objectives adopted in a multicultural education environment differ from other classroom settings. It has been explained by the post-migration ecology theory developed by Anderson, Hamilton, Moore, Loewen, and Frater-Mathieson (2004) and five dimensions of multicultural education developed by Banks and Banks (1995). According to post-migration ecology theory, refugee children reflect their past experiences and expectations of their ecosystems, and their roles within those ecosystems. They must adjust to the emergent demands and relationships of new ecosystem with the passing of time from pre-migration to post-migration. The major task of the schools and services within the hosting country is to manage the transition procedureas smoothly as possible as well as the refugee children and their families. According to Banks and Banks (1995), content integration, knowledge construction process, prejudice reduction, equity pedagogy and empowering school culture and social organization constitutes the five dimensions of multicultural education. They are: 
- Content integration: The use of various contents and specific examples from different cultures in teaching.

- Knowledge construction: Teachers' assisting students in understanding, discovering, and analysing how knowledge is constructed through implicit cultural assumptions and frameworks.

- Equity pedagogy: The use of instructional and pedagogical modifications necessary to facilitate the educational achievement of different groups of students.

- Prejudice reduction: Children's developing positive attitudes towards different cultures and racial groups.

- Empowering school culture and social structure: It can be explained as an attempt to experience equality through establishing a school-wide transformation, building relevant value system, and exploring the interaction of educators, students, parents, and society. In this regard, the efforts towards the inclusion of Syrian students in the formal education of Turkey can be alleged to be compatible with the 5 dimensions of multicultural education (Arar, Örücü\& Ak Küçükçayır, 2019).

In this study, the multicultural learning environment is limited to the process of inclusion of refugee students in formal education. Based on the investigation of the studies in literature, it was observed that Bogotch and Kervin (2019) in Canada, Bogotch, Faubert, Pfeifer, Wieckert, Kervin and Pappas (2020) in Canada and Germany, López, Lee\& Tung, (2020) in England, Merchant, Johansson\& Ärlestig (2020) in Sweden and US, Charles \& Denman, (2013); Mahfouz, El-Mehtar, Osman, and Kotok (2019); REACH \& UNHCR, (2014); Shuayb, Makkouk\& Tuttunji's (2014) in Lebanon carried out research on the education of Syrian students. Based on them, it was concluded that great many studies were carried out in schools to cope with communication problems, to overcome the trauma experienced by children and to ensure cultural harmony during the inclusion of Syrian students in the existing education system (Bogotch and Kervin, 2019), the responsibility for the successful integration of newcomers were assigned to local educators (Bogotch et al., 2020), the school administrators were found to be focused primarily on creating a stable educational environment, resolving urgent issues, and attending to basic needs of refugee students in this process, and there were problems such as inadequate physical equipment, high tendency of violence in student behaviour due to the experience of war, cultural differences and a decrease in academic achievement in the process of adaptation to a new education system (Mahfouz, El-Mehtar, Osman, and Kotok, 2019).

A review of the relevant literature on the education of Syrian refugees in Turkey revealed certain studies on the educational problems of Syrian refugee children who are mostly educated in public primary schools and on solution offers of their teachers and school administrators (Arar, Örücü\& Ak Küçükçayır, 2018), tried to determine the educational problems of Syrian refugee children studying at formal primary schools through the opinions of classroom teachers and school counsellors (Cirıt-Karaağaç, 2018), school administrators (Levent \& Çayak, 2017) and Syrian refugees (Kaya, 2016). Also the needs and conditions of schools, where refugee students also study, examined from the perspective of psychological counsellors at those schools (Özel, 2018); and tried to determine the educational difficulties of Syrian students through the opinions of students and teachers, and investigated educational policies which aimed to overcome such difficulties (Saklan, 2018). In this respect, Yiğit (2015) and Şensin (2016) also examined the 
opinions of teachers, students and school administrators, and classroom teachers, respectively, to identify educational implementations for and problems of refugee children in Turkey and to determine possible solutions. Özcan (2018) examined the legislative regulations to determine whether the education policy followed by Turkey for Syrians followed liberal multiculturalism and conducted interviews with Syrian and Turkish educators. Bozkurt (2018) aimed to examine teachers' attitude towards refugee students, measure their psychological resilience in this regard and reveal the general problems of teachers. Ateşok (2018) addressed the issue in the context of political sciences and investigated the content of education policies and whether the quality of the education given was suitable, from a multidisciplinary perspective.

When all these studies are examined, it can be observed that the process is considered to be a crisis in all countries where refugees are resided, and it is not an easy process for Syrian children to be integrated into education after asylum. By the year of 2017, 604,183 Syrian students entered the Turkish education system (ERI, 2017). It made Turkey the country that integrated the highest number of refugee students into the education system. In addition, most of the teachers had to carry out educational activities in multicultural classroom settings, where at least half of the class size consisted of students whose mother tongue was not Turkish after the integration procedure in the region where the research was conducted. This crisis situation makes it necessary to examine the quality of the right to education of both Turkish and Syrian students in schools that struggle to provide education with teachers who do not have experience in multicultural classes and with available physical equipment from the perspective of students, educators and families which are the main components of the educational process. However, no specific study has been found in which the integration of Syrian students into formal education is examined together with the perspectives of the primary stakeholders of education and training processes. The research results are hoped to contribute to the enhancement of studies conducted on the educational integration process in Turkey and in other countries accepting refugees, providing qualifications to meet the expectations and needs of all stakeholders, and the development of governmental policies in the field of education.

\section{Purpose of the Study}

The purpose of this study is to examine the opinions of classroom teachers, administrators, students, and parents regarding the inclusion of refugee students in Turkey's formal education system. The sub-objectives of the study are:

1) As for the process of including refugee students in formal education, what are the teachers', administrators', students', and parents'

a. opinions on the process?

b. opinions on the efforts conducted within the process?

c. suggestions for increasing efficiency of the process?

\section{Method}

The research is a qualitative study with a case study model. A case study is a research method that focuses on the questions of "how" and "why" and is used when researchers have little or no control over the events and connection between the event and the real life is not clear enough (Yıldırım \& Şimşek, 2011). 


\section{Study Group}

This research was carried out in Gaziantep, which is one of the cities hosting the greatest number of Syrian refugees in Turkey, during the 2017-2018 academic year. Throughout Gaziantep, which is the number one city to witness the highest level of immigration from Syria to Turkey, 1,515 Syrian students are receiving formal education within the framework of the Provincial National Education Guest Student Practice (Bozkurt, 2018). During the selection of study group, three primary schools with the highest number of refugee students were identified, and the study enrolled 24 classroom teachers and eight administrators from these schools, as well as 12 Turkish and 12 refugee students and parents of eight Turkish and eight refugee students. The study group was selected based on the criterion sampling method, which is a type of purposeful sampling. At least half of the class size should have been refugee students as the criterion in determining the study group. This way, as specified by Patton (2002), the researchers attempted to reach the information-rich cases in line with the purpose of the study.

11 of the teachers in the study group were female and 13 were male. Six of them were teaching first graders, six teachers were teaching second graders, another six were teaching third graders and another six teachers were teaching fourth graders. It was found that nine of the participating teachers did not have any refugee students in their class before, while eight of the remaining 15 teachers were educating foreign students for the last two years and the remaining seven were educating foreign students for the one year prior. Seven of the teachers had a seniority of 1-10 years and another seven had a seniority of 1120 years while the seniority level of the remaining ten was 21 years and over. Of the eight participating administrators, five were school principals and three were deputy principals. Of the participating administrators, three of them had a seniority of 1-10 years and five of them had 11-20 years seniority, and five of them have been administrators for 0-5 years while three of them have been administrators for 6-10 years.

Half of the twelve Turkish and twelve refugee students were third-grade students while the other half was fourth-grade students. As for the sixteen participating parents, four of them were mother, eleven of them were father and one of them was uncle. Of these parents, seven were parents of female students, and nine were parents of male students.

\section{Data Collection Tool}

For this research, data was collected using a semi-structured interview forms separately prepared for teachers, administrators, students, and parents.

\section{Semi-structured interview form}

The interview forms asked their opinions on the inclusion of refugee students in formal education and on efforts conducted at school, in classroom and in terms of schoolparent collaboration during this process, and for their suggestions to increase efficiency of the inclusion process. Within the scope of validity study, the semi-structured interview forms were presented to a total of six experts working at Gaziantep University in measurement and evaluation, psychological counselling and guidance, and classroom teaching areas, for their advice. And a pilot implementation was performed with two teachers, two administrators, two students and two parents. Interview forms were finalized upon the advice of expert opinions and the pilot implementation.

\section{Data Collection}

At the data collection phase, the participants in the study group were informed 
about the purpose of the study, and the interviews were performed by the researchers at schools with a one-on-one approach. All interviews were audio recorded and took around 20 minutes with teachers and administrators, and around 15 minutes with students and their parents. Although Syrian students and their parents can speak Turkish, a interpreter also attended in the interviews, and the procedure was supported to make certain statements clear.

\title{
Data Analysis and Interpretation
}

Content analysis was used in data analysis. Content analysis is the conceptualization of the obtained data, and then the logical arrangement based on the emerging concepts and the formation of themes that explain the data accordingly (Creswell, 2008). At this phase, the data collected through the voice recorder were first transferred to the electronic environment. While coding, the texts were read over several times and the codes were formed according to the research objectives based on the connotation or denotation of the research data. Table 1 shows a sample procedure regarding the coding process.

Table 1 An Example of Coding for the First Question of Teacher Interviews

Question: What are your opinions on the integration of foreign students into formal education?

T3: Under normal conditions, it is positive that they have to learn Turkish necessarily. It contributes to the adaptation process. However, it is unfruitful as they have language problems such as not being able to express themselves.

\author{
-Supporting Turkish \\ learning \\ -Promoting the adaptation \\ process \\ -Language/ communication \\ problem
}

T11: I think it had positive and negative effects. On the positive side, it freshened the classroom atmosphere and we got to know students from different cultures. On the negative aspect, foreign students experienced adaptation - Recognition of students from different cultures - Adaptation problem problems.

T15: As most of the foreign students do not speak language, they cannot understand the lesson in Turkish and the provided education is not efficient for themselves. A practice that hinders the educational procedure.

-Language/communication problem - An inefficient practice - Disruption of education

After the codes were formed, themes were created through identifying the similarities and differences of the emerging codes and bringing together those related to each other. While presenting the identified themes and codes, the direct quotations of student expressions were included in quotes. The pseudonyms of "T1" for the first interviewed teacher, "A1" for the administrator, "TS1" for the Turkish student, "RS1" for the refugee student, "TP1" for the parent of Turkish student and "RP1" for the parent of refugee student were used. For triangulation of the data, different groups (teachers, administrators, parents, and students) were interviewed in this study. Thus, different perspectives, meanings, indicators, and sources related to the event and phenomenon under investigation were attempted to be revealed to learn different aspects and occurrences of 
truth. By this means, it was struggled to ensure that the researchers can examine the same study from different perspectives and make strong inferences. Triangulation involves cross check of the results and information reached by using different data sources, methods, and researchers. Triangulation may include more than one researcher (Creswell, 2008). For this reason, a second encoder was assigned to analyse the data and the codes and themes that were agreed or disagreed upon were determined through the analysis of the other encoder. The reliability coefficient between the two encoders was estimated to be .92 based on the formula of "Encoder Reliability Coefficient= Consensus/ (Consensus + Dissensus X 100)".

\section{Findings}

Results with respect to the purposes of the research are presented in this section, respectively.

\section{Opinions on the Inclusion of Refugee Students in Formal Education}

The opinions on the inclusion of refugee students in formal education are presented by assessing the opinions of teachers and administrators, Turkish students and Syrian students, and Turkish parents and Syrian parents collectively. Results of the analysis of the opinions of teachers and administrators regarding the process are provided in Table 2.

Table 2

Opinions of Teachers and Administrators on the Process

\begin{tabular}{llcc}
\hline Themes & Codes & Teacher & Administrator \\
& & $\mathrm{f}$ & $\mathrm{f}$ \\
\hline \multirow{3}{*}{ Adaptation } & Language/communication problem & 19 & 6 \\
& Promotion of adaptation process & 8 & 5 \\
& Adaptation problems & 7 & 2 \\
\hline \multirow{5}{*}{ Education } & An inefficient implementation & 5 & 8 \\
and training & Disruption of education and & 6 & 1 \\
& teaching & 5 & 3 \\
& Emergence of behavioural problems & 5 & 1 \\
& Promotion of learning Turkish & 4 & - \\
& Deterioration of classroom & 5 & - \\
& arrangement & & - \\
& Decreased level of education & 2 & - \\
& Age differences among students & 2 & 3 \\
& Increased class size & 1 & - \\
Social life & The creation of cultural cohesion & 4 & - \\
& Improved living conditions & 3 & \\
& The recognition of students from & 3 & \\
& different cultures & & \\
\hline
\end{tabular}

In Table 2, it is observed that the opinions of teachers and administrators are gathered under three themes: adaptation, education and training and social life. The most prominent code among the findings was language/communication problem. It was declared both by administrators and teachers that inclusion in formal education supported the adaptation process and ensured cultural cohesion. However, some of the teachers and all the administrators found the implementation inefficient due to the reasons such as adaptation problems, the disruption of education, the occurrence of behaviour problems and the 
deterioration of classroom arrangement. When the findings are examined, it is noteworthy that the unfavourable views about the implementation surpass the favourable ones. Statements of teachers and administrators in this regard are as follows:

It is positive since it requires them to learn Turkish. However, it is negative as they had problems such as inability to express themselves during this period (T3).

I think that it had both positive and negative impacts. As for the positive aspects, the implementation juiced up the classroom and we got to know students from a different culture. As a negative aspect, foreign students had adaptation issues (T11).

It can be correct in terms of fitting into society; however, first they should learn to speak Turkish (T16).

I definitely find this implementation wrong. Because the productivity of lessons decreases when student groups of two different cultures are in the same classroom. Also, behavioural problems emerge (A8).

Table 3

Opinions of Students on the Inclusion of Refugee Students in Formal Education

\begin{tabular}{clcc}
\hline Themes & Codes & $\begin{array}{c}\text { Turkish } \\
\mathrm{f}\end{array}$ & $\begin{array}{c}\text { Syrians } \\
\mathrm{f}\end{array}$ \\
\hline \multirow{5}{*}{ Adaptation } & Exclusion of refugees & 2 & 12 \\
& Language/communication problem & 9 & 8 \\
& Ability to adapt & 5 & 1 \\
& Inability to adapt & - & 3 \\
\hline \multirow{5}{*}{ Education } & Incorrect implementation/no contribution & 5 & - \\
and & Deterioration of classroom arrangement & 5 & - \\
training & Unecreased course efficiency & 2 & 1 \\
& Much repetition during lesson (boring) & - & 6 \\
& Crowded classes & 1 & - \\
& Idle time for Turkish students in lessons & 1 & - \\
& Language learning & - & 1 \\
\hline \multirow{2}{*}{ Social life } & Recognition of different cultures & 1 & - \\
& Learning to cooperate & 1 & - \\
\hline \multirow{2}{*}{ Attitude } & Don't like - not being satisfied & 6 & - \\
& No difference & 5 & - \\
& Being happy to be educated & - & 3 \\
& No change & 1 & - \\
\hline
\end{tabular}

In Table 3, it is seen that opinions of Turkish and Syrian students on the implementation are divided into four themes, i.e. adaptation, education and training, social life, and attitude. While all Syrian students expressed that refugee students were excluded, the students in both groups stated that they had language/communication problems like teachers and administrators. Approximately half of the Turkish students noted that the 
process created cohesion among them. While Syrian students were in different opinions regarding the implementation's promotion of adaptation, Turkish students did not comment on this issue. Like the opinions of teachers and administrators, it was observed that Turkish students considered inclusion in formal education as an incorrect practice. Their salient negative opinions were that the classroom arrangement was deteriorated, the class was repeated a lot and the class became crowded. The decrease in course efficiency was articulated by both Turkish and Syrian students. Syrian students pointed out that they had difficulty in classes and idle time for Turkish students in lessons increased. Turkish students mostly uttered that they were not satisfied with the implementation while refugee students voiced that they were happy to be educated. These opposing views can be interpreted as an indication that mutual cohesion has not been achieved, yet.

Some statements of the students are:

We learned the language and it facilitated our bonding (TS1).

I'm happy to receive such education. We receive education together with my Turkish friends without any problem (RS3).

Both student groups consider the implementation negative because of language and communication problems, and Turkish students expressed that they were not satisfied with the implementation, it did not have any contribution and it disturbed classroom organization. On the other hand, Syrian students did not express any negative opinion in this regard. A negative opinion expressed differently by a great majority of Syrian students from Turkish students is exclusion, whereas only a few Turkish students expressed this problem. According to these results, it is seen that Turkish and Syrian students have different perspectives on the implementation. In the research, only Turkish students expressed neutral opinions regarding the implementation. Almost half of the Turkish students expressed their opinion as "does not matter". Opinions of the students in this regard are as follows:

We cannot communicate as we do not understand their language (TS12).

I am so not satisfied with this situation; we cannot get on with them (TS1O).

I and my friends get bored a lot because the teacher always tells the same topics as they don't understand the lesson (TS8).

They did not accept us, they excluded us... (RS4)

They had time idling while our teacher was giving separate attention to us... we had communication problems (RS6).

In Table 4, it is seen that opinions of Turkish and Syrian parents on the process are divided into three themes, i.e., adaptation, education and training and social life and are mostly negative. Both groups of parents declared that they experienced language/communication problems like the opinions of teachers, administrators, and students. Syrian parents, like Syrian students, pointed to the problem of exclusion. The fact that Turkish parents, teachers, and administrators have not expressed an opinion on this 
issue makes us think that they are not aware of this problem. As with teachers and administrators, all Turkish and Syrian parents described the process as an inefficient practice. However, some of the Turkish parents pointed to the behavioural problems like teachers, and a Syrian parent stated that there was a decline in academic achievement.

Table 4

Opinions of Parents on the Inclusion of Refugee Students in Formal Education

\begin{tabular}{llcc}
\hline Themes & Codes & $\begin{array}{c}\text { Turkish } \\
\mathrm{f}\end{array}$ & $\begin{array}{c}\text { Syrians } \\
\mathrm{f}\end{array}$ \\
\hline Adaptation & Language/communication problem & 5 & 5 \\
& Exclusion & - & 2 \\
\hline \multirow{2}{*}{$\begin{array}{l}\text { Education and } \\
\text { training }\end{array}$} & An inefficient implementation & 8 & 8 \\
& Behavioural problems & 2 & - \\
& Decline in academic achievement & - & 1 \\
\hline \multirow{5}{*}{ Social life } & Providing cooperation/socialization & 4 & 1 \\
& Recognizing a different culture & 2 & 2 \\
& Making friends & 1 & 2 \\
& Creating an atmosphere of tolerance & 1 & - \\
\hline
\end{tabular}

In addition to these findings, both groups of parents find the practice positive in terms of cooperating and socializing, enabling to recognize a different culture and making friends. Opinions of parents in this regard are as follows:

We cannot get along as we do not speak their language (TP3).

There was a language problem because we don't know each other's language (RP2).

We do not know their language and culture, and we had communication problems $(T P 2)$.

It is an inefficient implementation arising compulsorily... (RP8).

There is not a single positive aspect, my child was excluded (RP5).

They learn to bond and cooperate with others. Now my child also helps their siblings with their lessons (TP8).

An environment of tolerance was created. They learned to help each other... (TP7).

The only positive aspect is cultural bonding... (RP4).

In summary, all stakeholders regarding the inclusion of refugee students in formal education agree that the process enables cooperation/socialization and recognition of different cultures, promotes the adaptation process, but language/communication problems 
arise. Moreover, the issue of exclusion, especially expressed by Syrian parents and students, emerges as the matter that primarily needs to be resolved in the process together with the language problem.

\section{Opinions on the efforts conducted during the process of including refugee students in formal education}

The opinions of teachers and administrators on the efforts conducted during the process of including refugee students in formal education are provided in Table 5.

Table 5

Opinions of Teachers and Administrators on the Efforts Conducted within the Process

\begin{tabular}{|c|c|c|c|}
\hline Themes & Codes & $\begin{array}{l}\text { Teacher } \\
\mathrm{f}\end{array}$ & $\underset{\mathrm{f}}{\text { Administrator }}$ \\
\hline \multirow{5}{*}{$\begin{array}{l}\text { Implementations } \\
\text { at school }\end{array}$} & Support for adaptation to school & 4 & 4 \\
\hline & $\begin{array}{l}\text { Communication via help of a } \\
\text { interpreter }\end{array}$ & - & 4 \\
\hline & Getting help from counselling service & 3 & 2 \\
\hline & Support for learning Turkish & 2 & - \\
\hline & There is no initiative conducted & 1 & 3 \\
\hline \multirow{11}{*}{$\begin{array}{l}\text { Implementations } \\
\text { in classroom }\end{array}$} & One-on-one attention & 11 & 2 \\
\hline & Implementing adaptation efforts & - & 7 \\
\hline & $\begin{array}{l}\text { Ensuring bonding by having students } \\
\text { involved in games }\end{array}$ & 7 & - \\
\hline & Ensuring participation in lessons & 3 & - \\
\hline & Support for learning Turkish & 3 & - \\
\hline & Support for communication & 3 & - \\
\hline & Giving duties and responsibilities & 3 & - \\
\hline & Benefiting from peer solidarity & 2 & - \\
\hline & Receiving translation support & 2 & - \\
\hline & Increasing the use of visual materials & 2 & - \\
\hline & $\begin{array}{l}\text { Solving problems by using games and } \\
\text { drama techniques }\end{array}$ & 1 & - \\
\hline \multirow{3}{*}{$\begin{array}{l}\text { Implementations } \\
\text { regarding school- } \\
\text { parent } \\
\text { collaboration }\end{array}$} & Communication with parents & 14 & 4 \\
\hline & $\begin{array}{l}\text { Giving priority to refugees when it } \\
\text { comes to aid granted to school }\end{array}$ & 2 & 1 \\
\hline & No initiative conducted & 1 & 2 \\
\hline
\end{tabular}

As seen in Table 5, the results were gathered under three themes, i.e. implementations at school, in classroom and in terms of school-parent collaboration, within the framework of the interview questions. Whereas teachers and administrators expressed the efforts conducted at school as support for the adaptation to school and getting help from counselling service, administrators additionally stated that communication was made via the help of a interpreter. Teachers expressed differently from administrators that efforts were carried out to support Turkish education. However, three administrators and one teacher in the research stated that there was no initiative conducted at school. It suggests that the initiatives vary from school to school and have no standard. Some explanations of teachers and administrators in this regard are as follows: 
We deal with all kinds of their problems to ensure their adaptation to school... adaptation relationships, etc... (T8).

Adaptation efforts are carried out (T14).

Our counselling service provides an adaptation seminar throughout the school (A2)....we communicate through interpreters (A2).

We do not have a school-wide initiative (A7)...teachers mainly had initiatives in their own classes (A8).

With regards to implementations in the classroom, most of the teachers expressed that they give one-on-one attention to refugee students and they try to ensure bonding by having students involved in games. In addition, it is seen that some teachers tried to ensure the participation of refugee students in lessons, they supported them in learning Turkish and communicating, and they gave duties and responsibilities to refugee students. Administrators stated that, within the scope of implementations in classroom, only adaptation efforts were made, and one-on-one attention was given to refugee students. In the light of these results, it can be said that teachers perform many implementations in the classroom, but administrators do not have enough information about these implementations. This situation might be interpreted as that some in-class efforts are carried out by personal initiatives of the teachers. Some statements of teachers and administrators in this regard are as follows:

Through one-on-one attention, efforts are made first to solve the language problem and then to carry them through to the other students' academic level (T4).

I try to make them feel welcomed in the classroom by assigning them various duties and responsibilities, and I also ensure that students communicate with them by involving them in games (T3).

According to opinions of both teachers and administrators, the most highlighted effort under school-parent collaboration is the communication with parents. Some of the administrators and teachers stated that refugee students are given priority when it comes to aids granted to school.

I distribute incoming aid to Syrians first, I look after them (A5).

I keep in touch with the families, I inform them (T19).

The opinions of Turkish and refugee students on the efforts conducted in classrooms regarding the process are provided in Table 6 . When Table 6 is examined, it is seen that the findings are gathered under two themes as implementations for refugee students and for all students. While Turkish students expressed that more attention was given to Syrian students, visual materials were used in lessons so that Syrian students could understand more easily, cooperative activities were undertaken and Syrian students had separate teaching, however Syrian students did not mention these efforts at all. Different from 
Turkish students, Syrian students mentioned that their efforts to make friends were supported, they were involved in games and adaptation efforts and activities to endear the school were carried out. The common effort expressed by the students is teaching Turkish to refugee students. Also, one Turkish and three Syrian students stated that no initiative was conducted in their classroom in this regard. Statements of some students regarding the efforts are provided below.

Our teacher shows more attention to them (TS8, TS9). Our teacher teaches them separately (TS11).

Our teacher makes us play games together with them (RS5).

No initiatives and activities were conducted. I have been trying to accommodate on my own since the opening of school (RS4).

Table 6

Opinions of Students on the Efforts Conducted within the Process

\begin{tabular}{llcc}
\hline Themes & Codes & $\begin{array}{c}\text { Turkish } \\
\mathrm{f}\end{array}$ & $\begin{array}{c}\text { Syrians } \\
\mathrm{f}\end{array}$ \\
\hline For all students & The promotion of friendship & - & 3 \\
& Cooperative activities & 2 & - \\
\hline \multirow{5}{*}{ For refugee } & More of interest & 3 & - \\
students & Ensuring cohesion through & - & 3 \\
& inclusion in games & & \\
& No work done & 1 & 3 \\
& Using visual materials & 2 & - \\
& Adaptation practices & - & 2 \\
& School ingratiation activities & - & 2 \\
& Teaching Turkish & 1 & 1 \\
& Separate lecturing & 1 & - \\
\hline
\end{tabular}

The opinions of Turkish and Syrian parents on the efforts within the process are provided in Table 7. As seen in Table 7, the results regarding parent opinions were gathered under three themes, i.e. implementations at school, in classroom and under schoolparent collaboration, within the framework of the interview questions. Parents were the stakeholders who expressed the least number of opinions on the practices carried out during the process. Both groups of parents stated that adaptation studies were conducted, Syrian students were supported to learn Turkish, and these students were directly interested and contacted. However, there were also parents who believed that there were no studies at school. This may be because parents have not been sufficiently involved in the initiatives at school and that the participation of parents in the process has only been limited to the interviews. The opinions of parents in this regard are as follows:

Nothing was done. Only the school principal had a discussion with the parents (RP6).

The teachers visited our home and gave separate attention to our children (RP8).... 
Not many things were done, sometimes they talk with parents at school (TP6).

Table 7

Opinions of Parents on the Efforts Conducted within the Process

\begin{tabular}{|c|c|c|c|}
\hline Opinions of Parents & Codes & $\begin{array}{l}\text { Turkish } \\
\mathrm{f}\end{array}$ & $\begin{array}{l}\text { Syrian } \\
\mathrm{f}\end{array}$ \\
\hline \multirow{2}{*}{$\begin{array}{l}\text { Implementations } \\
\text { at school }\end{array}$} & $\begin{array}{l}\text { No initiative was conducted } \\
\text { at school }\end{array}$ & 2 & 1 \\
\hline & $\begin{array}{l}\text { Teaching how to read and } \\
\text { write }\end{array}$ & 1 & - \\
\hline \multirow{3}{*}{$\begin{array}{l}\text { Implementations } \\
\text { in the classroom }\end{array}$} & $\begin{array}{l}\text { Implementing adaptation } \\
\text { efforts }\end{array}$ & 1 & 2 \\
\hline & $\begin{array}{l}\text { Support for learning } \\
\text { Turkish }\end{array}$ & 1 & 1 \\
\hline & One-on-one attention & 1 & 1 \\
\hline \multirow{2}{*}{$\begin{array}{l}\text { Implementations } \\
\text { regarding } \\
\text { school-parent } \\
\text { collaboration }\end{array}$} & $\begin{array}{l}\text { Communication with } \\
\text { parents }\end{array}$ & 4 & 1 \\
\hline & Home visits & - & 1 \\
\hline
\end{tabular}

Table 8

Suggestions of Teachers and Administrators for Increasing the Efficiency of the Process

\begin{tabular}{|c|c|c|c|}
\hline Themes & Codes & $\begin{array}{l}\text { Teacher } \\
\quad \mathrm{f}\end{array}$ & $\begin{array}{c}\text { Administrator } \\
\mathrm{f}\end{array}$ \\
\hline \multirow{3}{*}{$\begin{array}{l}\text { For } \\
\text { teachers }\end{array}$} & $\begin{array}{l}\text { Continuous communication with the } \\
\text { family should be ensured }\end{array}$ & 2 & - \\
\hline & $\begin{array}{l}\text { The experiences of veteran teachers } \\
\text { should be used }\end{array}$ & 2 & - \\
\hline & $\begin{array}{l}\text { Trainings should be given on the } \\
\text { process }\end{array}$ & 2 & - \\
\hline \multirow{5}{*}{$\begin{array}{l}\text { For } \\
\text { students }\end{array}$} & They should learn Turkish first & 15 & 2 \\
\hline & $\begin{array}{l}\text { Syrian students should be educated } \\
\text { separately }\end{array}$ & 7 & 6 \\
\hline & $\begin{array}{l}\text { Adaptation process must be carried } \\
\text { out first }\end{array}$ & 4 & - \\
\hline & Guidance service should work harder & 3 & - \\
\hline & Support training should be provided & 2 & - \\
\hline $\begin{array}{l}\text { For } \\
\text { parents }\end{array}$ & They should learn Turkish & 6 & - \\
\hline
\end{tabular}

Suggestions for Increasing the Efficiency of the Process of Including Refugee Students in Formal Education

The results regarding the suggestions of teachers and administrators for increasing the efficiency of the process are provided in Table 8 . When the suggestions gathered under three themes, namely suggestions for teachers, for students and for parents in Table 8, are examined, it is seen that teachers offered much more suggestions on the matter than 
administrators. The most prominent themes from the suggestions by teachers include giving priority to teaching Turkish to refugee students, giving education to refugee students separately, teaching Turkish to families also, and ensuring the adaptation process. The most significant suggestion by administrators for increasing the efficiency is separate education for Syrian students. Some expressions of teachers and administrators regarding their suggestions are provided below.

First of all, giving a good education for spoken Turkish would solve the problem to a great extent (T2).

Foreign students should receive education in a different place and, first of all, their language problem should be solved (T5).

Communication is difficult with parents who have language problems. Education can be given to the parents of foreign students (T6).

Foreign students should be educated by people and institutions from which they can get more efficiency (A1).

The results regarding the suggestions of Turkish and refugee students and their parents for increasing the efficiency of the process are provided in Table 9.

When the suggestions collected under two themes, namely education and adaptation, are examined, in Table 9, it is observed that the students have brought more suggestions than parents. Turkish students and all parents recommended that Syrian students should be taught separately and by Syrian teachers. The fact that Syrian students have not made any suggestions on this issue can be interpreted as they are satisfied with the current practice. However different from Turkish students, they suggested talking about the problems, preparing Turkish students also for this process, giving priority to completing the adaptation process and getting more support from the counselling service. Additionally, both student groups suggested giving priority to learning Turkish and increasing efforts at promoting bonding among students. Some expressions of students and their parents regarding their suggestions are provided below:

I think they should have a Syrian teacher who could speak their language and understand them (TS5).

Turkish courses can be given by professionals before enrolling them at Turkish schools (TS2)....

We should have been provided with classes to learn Turkish language and Turkish lessons a bit at a school without Turkish students (RS6).

The counselling service could have helped (RS8).

All Syrian students should be gathered at one single school and taken out of normal classes... (TP1).

I think their classes should be separated (TP2). 
If foreign students have different teachers and classes, they can receive a better education... (RP2).

Table 9

Suggestions of Students and Parents for Increasing the Efficiency of the Process

\begin{tabular}{|c|c|c|c|c|c|}
\hline Themes & Codes & $\begin{array}{l}\text { Turkish } \\
\text { Student } \\
\mathrm{f}\end{array}$ & $\begin{array}{l}\text { Syrian } \\
\text { Student } \\
\mathrm{f}\end{array}$ & $\begin{array}{l}\text { Turkish } \\
\text { Parent } \\
\text { f }\end{array}$ & $\begin{array}{l}\text { Syrian } \\
\text { Parent } \\
\quad \mathrm{f}\end{array}$ \\
\hline \multirow{3}{*}{$\begin{array}{l}\text { For } \\
\text { education }\end{array}$} & $\begin{array}{l}\text { Syrian students should have } \\
\text { separate education }\end{array}$ & 4 & - & 7 & 5 \\
\hline & $\begin{array}{l}\text { They should be educated by } \\
\text { Syrian teachers }\end{array}$ & 2 & - & 1 & 2 \\
\hline & $\begin{array}{l}\text { They should learn Turkish } \\
\text { first }\end{array}$ & 2 & 2 & - & - \\
\hline \multirow{6}{*}{$\begin{array}{l}\text { For } \\
\text { adaptation }\end{array}$} & $\begin{array}{l}\text { Inclusion studies should be } \\
\text { increased }\end{array}$ & 1 & 2 & - & - \\
\hline & $\begin{array}{l}\text { More attention should be } \\
\text { paid to Syrian students }\end{array}$ & 1 & - & - & - \\
\hline & $\begin{array}{l}\text { Turkish students should be } \\
\text { prepared for the process }\end{array}$ & - & 1 & - & - \\
\hline & $\begin{array}{l}\text { Adaptation process must be } \\
\text { completed first }\end{array}$ & - & 1 & - & - \\
\hline & $\begin{array}{l}\text { Problems should be } \\
\text { discussed }\end{array}$ & - & 2 & - & - \\
\hline & $\begin{array}{l}\text { More assistance from the } \\
\text { guidance service should be } \\
\text { provided }\end{array}$ & - & 1 & - & - \\
\hline
\end{tabular}

\section{Discussion}

When opinions on the process are examined, according to the research results, it is seen that all the participating groups considered the implementation positive, in terms of ensuring bonding and getting to know a different culture. The research also found that teachers and administrators regarded the implementation positive, in terms of its support for the adaptation process and for learning Turkish. Turkish students and parents emphasize the benefit of learning to help each other with respect to the positive aspects of the implementation, whereas adaptation and being happy to receive an education are highlighted by Syrian students. Cirıt-Karaağaç (2018), Kultas (2017) and Akalın (2016) determined that the refugee children liked school and Peterson, Meehan, Ali and Durrant (2017) found that, additionally, they were willing to learn. It is also seen in other studies that the positive psychosocial adaptation of refugee children is connected with social support services in the country of settlement, cultural integration, presence of peers of similar ethnicity and cultures, and a sense of belonging to school (Birman, Beehler, Harris, Everson, Batia\& Liautaud, 2008; Kia-Keating \& Ellis, 2007; Kovacev \& Shute, 2004). In this context, it can be said that the implementation is a meaningful step.

However, in the research, negative opinions on the implementation are much more numerous than positive opinions. It is also found that both Turkish and Syrian parents defined the process as a compulsory situation. All the participating administrators and 
parents and some of the teachers and Turkish students considered the implementation an inefficient one. The most significant problem regarding the application is the language and communication problem for all groups. In the review of the relevant literature, it is seen that the greatest problem is the language problem, regarding the inclusion of foreign students in formal education (Akalın, 2016; Ateşok, 2018; Bircan and Sunata, 2015; Bozkurt, 2018; Cirıt-Karaağaç, 2018; Dorman, 2014; Emin, 2016; Erdem, 2017; Erdoğan, 2015; Hart, 2009; Jones \& Rutter, 1998; Levent and Çayak, 2017; Özel, 2018; Özcan, 2018; Saklan, 2018; Szente, Hoot\& Taylor, 2006; Șensin, 2016; Tamer, 2017; Taylor \& Sidhu, 2011; Yiğit, $2015)$.

Moreover, with respect to the negative aspects of the implementation, teachers emphasized adaptation problems, disruptions in education, occurrence of behavioural problems and disturbed classroom organization whereas Turkish students expressed their dissatisfaction with the implementation, that the implementation did not have any contribution and the classroom organization was disturbed. Like the findings of this study, Sarıtaş, Şahin \& Çatalbaş (2016) and Dryden-Peterson (2015) also found that refugee children had problems in matters such as obeying classroom and school rules, fulfilling responsibilities, and following lessons, etc. It can be alleged that the main reason behind these problems is the language problem. While language problem negatively affects the academic achievement of refugee students according to Shuayb, Makkouk\& Tuttunji (2014) and Mahfouz, El-Mehtar, Osman, and Kotok (2019), it deteriorates their psycho-social and cultural cohesion based on Cirıt-Karaağaç (2018), Özel (2018), Kaya \& Kıraç (2016), İstanbul Bilgi University Child Unit (2015) and Dorman (2014). For Syrian students and parents, the most important problem regarding the implementation is exclusion. MercanUzun and Bütün (2016) found that children cannot socialize and are casted out of the group as they do not speak the language. Similarly, according to Sirin \& Rogers-Sirin (2015), many Syrian parents in Lebanon became reluctant to send their children to school in fear of verbal or physical abuse. Inability to communicate might cause the children are isolated from others and to become lonely at school, lead them to exhibit aggressive behaviours or become introverted as they cannot express themselves (Yohani, 2010). According to Özel (2018), school psychological counsellors are not able to communicate with refugee students, and thus, cannot deal with the resulting behavioural, psychosocial, familial, socio-cultural, adaptation and exclusion problems. It is hoped that overcoming the language learning and communication problems will enable the solution of many other problems, especially exclusion.

The study also examined the opinions regarding the efforts conducted during the inclusion of refugee students in formal education. In this context, the teachers and administrators expressed that support for adaptation to school, getting help from counselling service and support for learning Turkish were the efforts conducted at school while the some of the participants said that no initiative was conducted at school. This situation may be because the number of school counsellors at schools is insufficient in terms of taking care of students on one-to-one basis and constantly because of the high number of Syrian students at schools. For example, social workers, settlement workers and crisis counsellors who speak Arabic were assigned as may be required together with the Syrian students' starting their education at schools in Canada which had accepted fewer refugees when compared to Turkey (Bogotch \& Kervin, 2019).

Although a similar structure was also established in TECs in Turkey the process was attempted to be managed with the current teaching staff when Syrian students started to be taught in the same classes with Turkish students. Furthermore, some participants' 
expressions in that there are no initiatives at schools, might suggest that there is no unity in practice. According to Bircan and Sunata (2015), guidance services did not have a systematic approach at schools. These findings make it necessary for the efforts in schools to be standardized. What is more, the fact that the studies carried out for school-family cooperation are only limited to parent interviews may also cause parents who have no communication with schools to have the idea that there are no efforts at school. According to Aykırı (2017) and İmamoğlu \& Çalışkan (2017), teachers cannot communicate with many families even about the problems and needs of students. Even though there are difficulties, it is important to diversify the studies of parent involvement in order to ensure schoolparent cooperation and to inform the parents about the activities carried out in schools and to provide parents with language trainings in order to establish a healthier communication.

When the in-class efforts are examined as well as those in schools, it is seen from the research that many efforts were made by teachers for Syrian students such as giving oneon-one attention in the classroom, involving the students in games, ensuring their participation in lessons and supporting them in learning Turkish and communicating. These findings supported by student opinions yield that the teachers are willing to contribute to the process. Other studies in Turkey also found that the teachers were helpful for refugee students to adapt themselves to classroom environment (Mercan-Uzun \& Bütün, 2016; Özel, 2018; Şeker \& Sirkeci, 2015) and they (Aykırı,2017; Er \& Bayındır, 2015; Erdem, 2017; Sağlam \&Kanbur,2017; Şensin, 2016; Tamer, 2017) were found to have conducted great many studies similar to this one. However, when the practices determined in that research are evaluated, it cannot be claimed that the studies in which the five disciplines of multicultural education are consciously applied are in sufficient number.

This situation might be due to lack of sufficient knowledge of teachers in this regard. Yiğit (2015) determined that teachers lacked knowledge about multicultural education and did not receive sufficient training regarding multicultural education. In this regard, it can be alleged that it is a requirement to improve the competencies of teachers regarding education in multicultural classroom settings. Also, many efforts regarding the implementations in the classroom which were expressed by the teachers were not mentioned by the administrators and parents. In this context, it can be said that the administrators and parents do not know the entire in-class implementations. Administrators' lack of information about the implementations can be interpreted as that the implementations in the classroom are carried out via the personal efforts of teachers. These findings indicate that the coordination between the teacher, the administrator and the parent regarding the educational activities should be increased.

In the light of the study results, it is seen that the students assess the efforts in the classroom from their own perspectives. While Turkish students expressed that more attention was given to Syrian students, visual materials were used in lessons so that Syrian students could understand more easily, cooperative activities were undertaken and Syrian students had separate teaching, Syrian students did not mention these efforts at all and stated that their efforts to make friends were supported, they were involved in games, and adaptation implementations and activities to endear school were carried out. Similar practices were carried out in school settings in Sweden and in the UK (Merchant, Johansson\& Ärlestig 2020). Teachers' spending more time with Syrian students in the classroom is similar to other research results (Özel, 2018; Sarıtaş et al., 2016); however, according to Saklan and Enginer (2017) this situation causes some problems. For example, one Syrian student expressed in the research that Turkish students had idle time in classes. This situation led to a decrease in the academic success of Turkish students at schools 

in formal education before this process is completed. Social inclusion efforts can be increased at schools with the contributions of counselling services so that refugee students will not feel excluded. As this process is new also to Turkish students, initiatives can be planned to ensure their adaptation, too. In this new situation, measures can also be taken to preserve the educational standards of Turkish students. Efforts can be made to create awareness among Turkish and Syrian parents regarding the initiatives performed at school and in the classroom. Furthermore, based on the research results, it can be suggested to review and increase the efficiency of the in-service training for teachers and administrators, arrange the content of training in a manner that covers multicultural education, and make the training closer to hands-on training.

This study is limited to the interviews with teachers, administrators, students, and parents chosen among schools with a high number of refugee students. In a future study to be planned, the views of other stakeholders (e.g. policy makers, etc.) about the process can also be received and more detailed information about the process can be obtained through observations in schools/classrooms. One another limitation of this study was that its' being carried out at primary school level. A similar study to be conducted at other levels of schooling may enable comparative examination of what can be done in the process and the problems encountered.

\section{References}

Akalın, A. (2016). The educational problems of the Syrian refugee children in Turkey. Unpublished Master's Thesis, İstanbul Aydın University, İstanbul.

Akpinar, T. (2017). The problems of Syrian refugee children and women in Turkey in the context of social policy. Balkan and Near Eastern Journal of Social Sciences. 03 (03), 1629.

Anderson, A., Hamilton, R., Moore, D., Loewen, S. \& Frater- Mathieson, K. (2004). Education of refugee children: Theoretical perspectives and best practice. R. Hamilton \& D. Moore (Eds.), In Educational interventions for refugee children: Theoretical perspectives and implementing best practice (pp. 1-12). London: Routledge Falmer.

Arar, K., Örücü, D. \& Ak Küçükçayır, G. A. (2019). Dramatic experiences of educators coping with the influx of Syrian refugees in Syrian schools in Turkey. In Education, Immigration and Migration: Policy, Leadership and Praxis for a Changing World (pp. 145-167). US: Emerald Publishing Limited.

Arar, K., Örücü, D. \& Ak Küçükçayır, G. (2018). Culturally relevant school leadership for Syrian refugee students in challenging circumstances. Educational Management Administration E Leadership, 47(6), 960-979.

Ateşok, Z.Ö. (2018). Refugee education in the context of international refugee regime and the case of Turkey from a comparative perspective. Unpublished Master's Thesis, İstanbul University, İstanbul.

Aykırı,K. (2017). The opinions of the class teachers regarding the educational situations of the Syrian students in their classes. Turkish Journal of Primary Education, 2, 44-56.

Banks, C.A. \& Banks, J. A. (1995). Equity pedagogy: An essential component of multicultural education. Theory into Practice, 34(3), 152158.

Banks, J.A. (2017). Citizenship education and global migration: Implications for theory, research, and teaching. American Educational Research Association.

Bircan, T.\& Sunata, U. (2015). Educational assessment of Syrian refugees in Turkey. 
Migration Letters, 12(3), 226-237.

Birman, D., Beehler, S., Harris, E.M., Everson, M.L., Batia, K. \& Liautaud, J. (2008). International family, adult, and children enhancement services (faces): A community based comprehensive services model for refugee children in resettlement. American Journal of Orthopsychiatry, 78(1), 121-132.

Block, K., Cross, S., Riggs, E.\& Gibbs, L. (2014). Supporting schools to create an inclusive environment for refugee students. International Journal of Inclusive Education, 18(12), 1337-1355. doi: 10.1080/13603116.2014.899636.

Bogotch, I.\& Kervin, C. (2019). Leadership and Policy Dilemmas: Syrian Newcomers as Future Citizens of Ontario, Canada. Khalid Arar Jeffrey S. Brooks Ira Bogotch (ed.) Education, Immigration and Migration (Studies in Educational Administration). US: Emerald Publishing Limited.

Bogotch, I., Faubert, B., Pfeifer, M., Wieckert, S., Kervin, C.\& Pappas, D. (2020). Political and economic gamble: why two jurisdictions in Canada and Germany made the right decisions in welcoming Syrian newcomers, 2015-present. International Journal of Leadership in Education, 23(1), 40-60.

Bozkurt, S. (2018). School teachers 'views on Syrian students' education in Turkey: Gaziantep example. Unpublished Master's Thesis, Üsküdar University, İstanbul.

Bulut, Y. (Ed.) (2015). Uluslararası göç ve mülteci uyumu sorununda kamu yönetiminin rolü. [The role of public administration in the problem of international migration and refugee integration]. Kocaeli: Umuttepe Publications.

Cirıt-Karaağaç, F. (2018). Educational problems of Syrian refugee students in elementary schools. Unpublished Master's Thesis, Yeditepe University, İstanbul.

Charles, L.\& Denman, K. (2013). Syrian and Palestinian Syrian refugees in Lebanon: The plight of women and children. Journal of International Women's Studies, 14(5), 96-1 11.

Connor, P. (2018). Most displaced Syrians are in the Middle East, and about a millionare in Europe. Pew Research Center. Retrieved on 21.12.2019 from http://www. pewresearch.org/fact-tank/2018/01/29/where-displaced-syrianshave-resettled/

Creswell, J. W. (2008). Educational research: Planning, conducting, and evaluating quantitative and qualitative research. New Jersey: Pearson Merrill Prentice Hall.

Directorate General of Migration Management, (2016).Geçici korumamız altındaki Suriyeliler [Syrians under temporary protection]. Retrieved on 13 November 2018 from http://www.goc.gov.tr/icerik3/gecici-korumamiz-altindakisuriyeliler_409 558_560, 2016.

Dorman, S. (2014). Educational needs assessment for urban Syrian refugees in Turkey. YUVA Association Report. Istanbul: UNHCR. Retrieved on 12 October 2018 from http://data. unhcr. org/syrianrefugees/download. php.

Dryden- Peterson, S. (2015). Education of refugees in countries of first asylum: What teachers need to know about the pre-resettlement experiences of refugee children. Washington, DC: Migration Policy Institute.

Emin, M.N. (2016). Türkiye'deki Suriyeli çocukların eğitimi. [Syrian children's education in Turkey]. İstanbul: SETA Publications.

Er, A.R.\& Bayındır, N. (2015). Pedagogical approaches of elementary teachers for primary refugee children. International Journal of Social and Educational Sciences, 2(4), 175-185.

Erdoğan, M.( 2015). Syrians in Turkey report. Retrieved on 23.01.2018 from https:// mmuraterdogan.com/2016/06/06/raporlar/.

Erdem,C. (2017). Instructional problems experienced by primary school teachers who have 
refugee students in their classes and their solutions for problems. Medeniyet Journal of Education Researches, 1(1),26-42.

Ereş,F.(2015). Problematic of migrant education and diversity management for immigrant education in Turkey. Çankir Karatekin University Journal of Institute of Social Sciences, 6(2), 17-30.

ERI (Education Reform Initiative) (2017). Education monitor report. Retrieved on 20.04.2018 from http://www.egitimreformugirisimi.org/egitim-izleme-raporu2016-17/

Hart, R. (2009). Child refugees, trauma, and education: Inter-actionist considerations on social and emotional needs and development. Educational Psychology in Practice, 25(4), 351-368.

İmamoğlu, H.V.\& Çalışkan,E. (2017). Opinions of teachers on the primary education of foreign students in public schools: The case of Sinop province Karabük University Journal of Institute of Social Sciences, 7(2), 529-546.

İstanbul Bilgi University Child Studies Unit (2015). Suriyeli mülteci çocukların Türkiye devlet okullarindaki durumu: Politika ve uygulama önerileri. [Syrian refugees in Turkey the situation of children in public schools: Policy and practice recommendations] Retrieved on 12.05.2019 from http://cocuk.bilgi.edu.tr/wpcontent/uploads/2015/09/SuriyeliCocuklar-Egitim-Sistemi-Politika-Notu.pdf.

Jones, C.\& J. Rutter. (1998). Mapping the field: Current issues in refugee education. C. Jones and J. Rutter (Ed.). In Refugee education: Mapping the field (Chap.1). Oakhill:Trentham Books.

Khattab, L. (2017). School for stability: Examining the role of education in fostering social stability in Lebanon. Beirut: International Alert. Retrieved on 14.11.2018 from https://www.international-alert.org/publications/school-for-stability

Kaya, A. S. (2016). The problems of Syrian refugees in Turkey: Nizip example. Unpublished Master's Thesis, İstanbul Yeni Yüzyll University, İstanbul.

Kaya, A.\& Kıraç, A. (2016). Vulnerability assessment of Syrian Refugees in İstanbul. İstanbul: Support to life.

Kia-Keating, M.\& Ellis, B. H. (2007). Belonging and connection to school in the resettlement: Young refugees, school belonging, and psychosocial adjustment. Clinical Child Psychology and Psychiatry, 12, 29-43.

Kirmayer, L.J., Narasiah, L., Munoz, M., Rashid, M., Ryder, A., Guzder, J. \& Pottie, K. (2011). Common mental health problems in immigrants and refugees: general approach in primary care. Canadian Guidelines for Immigrant Health. 183(12), 959967.

Kovacev, L.\& Shute, R. (2004). Acculturation and social support in relation to psychosocialadjustment of adolescent refugees resettled in Australia. International Journal of Behavioural Development, 28, 259-267.

Koc, M, Gorucu, I\& Akbiyik, N. (2015). Suriyeli sığınmacılar ve istihdam problemleri. [Syrian refugees and employment problems]. Birey ve Toplum, [Individual and Society], 5 (9), 63-93.

Kultas,E.(2017). The education problem of the Syrian refugees located in Turkey (Sample for Van City). Unpublished Master's Thesis, Yüzüncü Yıl University, Van.

Levent, F.\& Çayak, S. (2017). School administrators' views on Syrian students' education in Turkey. HAYEF Journal of Education:14(27), 21-46. 
López, R.M., Lee, J.J.\& Tung, R.(2020). Implementing a summer enrichment program for secondary newcomer students in a New England community. International Journal of Leadership in Education, 23(1), 77-92.

Mahfouz, J., El-Mehtar, N., Osman, E.\& Kotok, S. (2019). Challenges and agency: principals responding to the Syrian refugee crisis in Lebanese public schools. International Journal of Leadership in Education, 1-17.

Maya,İ. (2016). Ilkokul ve ortaokul öğretmenlerinin çok kültürlü sınıf ortamlarında sınıf yönetiminde karşılaştıkları sorunlar ve bu sorunlar için kullandıkları stratejiler. ¿Problems encountered by primary and secondary school teachers in classroom management in multicultural classroom environments and the strategies used for these problems]. K. Beycioğlu, N. Özer, D. Koşar, İ. Şahin (Eds.) In Eğitim yönetimi araștırmaları [Education management research]. (p. 420-434).Ankara:PegemAkademi Publishment.

Mercan-Uzun, E.\& Bütün, E. (2016). Okul öncesi eğitim kurumlarındaki Suriyeli sı̆̆ınmacı çocukların karşılaştıkları sorunlar hakkında öğretmen görüşleri. [Teacher views on the problems faced by Syrian refugee children in preschool education institutions]. International Journal of Early Childhood Education Studies, 1(1), 72-83.

Merchant, B., Johansson, O.\& Ärlestig, H. (2020). Welcome and välkommen school administrators in the US and Sweden responds to unexpected numbers of refugees in their rural communities. International Journal of Leadership in Education, 23(1), 2439.

Ministry of National Education (2013). Ülkemizde geçici koruma altinda bulunan Suriye vatandaşlarına yönelik ĕ̆itim öğ retim hizmetleri genelgesi. [Circular on education services for Syrian citizens under temporary protection in our country]. Retrieved on 23.07.2018 from http://mevzuat.meb.gov.tr/html/yabyonegiogr_1/yabyonegi ogr_1.html

Ministry of National Education (2014). Tabancılara yönelik ĕgitim-öğretim hizmetleri. [Education services for foreigners]. Retrieved on 12.06 .2018 from http://www. meb.gov.tr/mevzuat/liste.php?ara=1.

Oytun, O.\& Gündoğar, S. S. (2015). Suriyeli sığınmacıların Türkiye’ye etkileri raporu. [The effects of Syrian refugees in Turkey report]. Ankara: ORSAM- TESEV.

Özcan, A. (2018). Çok kültürlülük bağlamındaTürkiye’nin Suriyeli öğrencilere yönelik eğitim politikası. [Turkey oriented towards multiculturalism Education Policy in the Context of Syrian Students ]. PESA International Journal of Social studies, 4(1), 17 29.

Özel, D. (2018). Examining needs and issues of refugee- receiving schools in Turkey from the perspectives of school counselors. Unpublished Master's Thesis, Middle East Technical University, Ankara, Turkey.

Özer, Y., Komsuoğlu, A., Ateşok, Z.Ö. (2016). Education of Syrian children in Turkey: Problems and suggestions. ASOS Journal, 4(37), 76-110.

Özkarsll, F. (2014). Migration from Syria to Turkey and informal employment of Syrians (Example of Mardin). Unpublished Master's Thesis, Artuklu University, Mardin.

Pala, A. (2013). Forced migration and women experience: Example of Diyarbakir Unpublished Master's Thesis, Hacettepe University, Ankara.

Patton, M. Q. (2002). Qualitative research and evaluation methods. Thousand Oaks: Sage Publications. 
Peterson, A., Meehan, C., Ali, Z. \& Durrant, I. (2017) What are the educational needs and experiences of asylum-seeking and refugee children, including those who are unaccompanied, with a particular focus on inclusion? A literature review. Canterbury: Canterbury Christ Church University.

Phinney, J. S., Horenczyk, G., Ljebkind, K.\& Vedder, P. (2001). Ethnic identity, immigration, and well-being: An interactional perspective. Journal of Social Issues, 57, (3), 493-510.

REACH \& UNHCR. (2014). Barriers to education for Syrian refugee children in Lebanon: Outof-school children profiling report. Retrieved on 11.07 .2018 from http://www.reachresourcecentre.info/system/files/resource-documents/reach_ lbn_report_syriacrisis_outofschoolchildrenprofiling_nov2014.pdf

Sağlam, H. İ.\& Kanbur, N. İ. (2017). Investigation attitudes towards refugee students of class teachers' in terms of several variables. Sakarya University Journal of Education, 7(2), 310-323.

Sakız, H.(2016). Migrant children and school cultures: A suggestion for inclusion. Journal of Migration, 3(1),65-81.

Saklan, E. (2018). Analysis of educational process on Syrian school-age children in Turkey. Unpublished PhD Thesis, Ankara University, Ankara.

Saklan, E. \& Erginer, A. (2017). Classroom management experiences with Syrian refugee students. Education Journal, 6(6), 207-214.

Sandal, E. K., Hançerkıran, M.\& Tıraş, M. (2016).Syrian refugees in Turkey and their reflections in Gaziantep province. Gaziantep University Journal of Social Sciences. 15(2), 461-483.

Sarıtaş, E., Şahin, Ü. \& Çatalbaş, G. (2016). Problems faced with foreign students in primary schools. Pamukkale University Journal of Social Sciences Institute, 25(1),208229.

Seydi, A. R. (2014). Policies of Turkey regarding the solution of educational problems of Syrian refugees. Süleyman Demirel University Science and Literature Faculty Journal of Social Sciences, 31, 267-305.

Shuayb, M., Makkouk, N. \& Tuttunji, S. (2014). Widening access to quality education for Syrian refugees: The role of private and NGO sectors in Lebanon. Lebanon: Centre for Lebanese Studies. Retrieved on 19.12.2019 from http://search.shamaa.Org/ PDF /Reports/LEa22 445Shuayb2014.pdf

Sirin, S. R.\& Rogers-Sirin, L. (2015). The educational and mental health needs of Syrian refugee children. Washington, DC: Migration Policy Institute.

Syrian Centre for Policy Research (SCPR) (2015). Alienation and Violence Syria March. 2015 Impact of Syria Crisis Report 2014. Damascus, Syria. Retrieved on 19.12.2019 from http://www.unrwa.org/sites/default/files/alienation and violence impact of the syriacrisis in 2014 eng.pdf

Szente, J., Hoot, J.\& Taylor, D. (2006). Responding to the special needs of refugee children: Practical ideas for teachers. Early Childhood Education Journal, 34 (1), 15-20.

Şeker, B. \& Sirkeci, İ. (2015). Challenges for refugee children at school in eastern Turkey. Economics and Sociology, 8(4), 122-133. doi:10.14254/2071-789X.2015/8-4/9.

Şensin, C. (2016). The evaluation of primary school teachers' views regarding the education of Syrian immigrant students. Unpublished Master's Thesis, Uludağ University, Bursa.

Tamer,M.G. (2017). Syrian refugee children in public schools in Trabzon. Journal of Migration, 4(2),119-152. 
Taştan, C.\& Çelik, Z. (2017). Türkiye'de Suriyeli çocukların eğitimi: Güçlükler ve öneriler. [Syrian children's education in Turkey: Challenges and recommendations]. Ankara: Eğitim-Bir-Sen Strategic Research Center.

Tösten, R., Toprak, M. \& Kayan, M.S. (2017). An investigation of forcibly migrated Syrian refugee students at Turkish public schools. Universal Journal of Educational Research, 5(7), 1149-1160.

Tunç, A. Ş. (2015). Refugee behaviour and its social effects: An assessment of Syrians in Turkey. Turkish Journal of TESAM Academy, 2(2), 29-63.

Taylor, S. \& Sidhu, R. (2011). Supporting refugee students in schools: What constitutes inclusive education. International Journal of Inclusive Education. 16(1):34-56.

UNICEF Connect (2015). The Syrian conflict and Europes' refugee crisis in numbers. Retrieved on 23.01.2018 from https://blogs.unicef.org/blog/the-syrian-conflictand-europes refugee-crisis-in-numbers /

Yavuz, Ö.\& Mizrak, S. (2016). Education of school-age children in emergencies: The case of Syrian refugees in Turkey. Journal of Migration.3 (2), 175-199.

Yıldırım, A. \& Şimşek, H. (2011). Sosyal bilimlerde nitel araştırma yöntemleri. [Qualitative research methods in the social sciences ]. Ankara: Seçkin Publications.

Yiğit, T. (2015). The education of refugee children in Turkey in the context of applications and issues: The sample of Kirşehir and Nerşehir. Unpublished Master's Thesis, Ahi Evran University, Kurşehir.

Yohani, S. (2010). Nurturing hope in refugee children during early years of post-war adjustment. Children and Touth Services Review, 32(6), 865-873.

\section{About the Authors}

Melike Özyurt is an assistant professor in the Department of Educational Sciences at the Faculty of Education in Gaziantep University. Her area of expertise is curriculum development and instruction. Her research interests include, school based curriculum development, high order thinking skills, and 21 st century skills. She aims to contribute to the field of teacher training with her recent studies on instructional metacognition and Understanding by Design. She has coordinated several EU projects, but most recently she coordinated an EU Project on social inclusion and 21 st century skills.

Bilge Kuşemir Kayıran is an assistant professor in the Department of Elementary Education at the Faculty of Education, Gaziantep University. Her area of expertise is curriculum development and instruction. Her academic publications include studies on Turkish and mathematics curricula. Her research interests also include, Turkish instruction, learning difficulties in native language and teaching children to read and write. She is also expert in teaching with drama and organizes drama workshops for teachers, prospective teachers and students. She has recently contributed as a researcher in an EU project on social inclusion and 21 st century skills.

Şükran Tüfekçi Küçükoğlu is working as a classroom teacher at the Ministry of National Education, Turkey, since 2014. She graduated from the Department of Elementary Education at Kazım Karabekir Faculty of Education, Atatürk University in 2013. She took her master's degree from Gaziantep University, Department of Elementary Education, Primary Education Program in 2019. She wrote her master's thesis on the investigation of the metacognitive awareness levels of primary school students. Her research interests are teaching in multicultural classroom settings and metacognition. She has teaching experience in multicultural classroom settings. 